\title{
Public Administration Reform in Bulgaria: Top-down and Externally-driven Approach
}

\author{
Emilia Zankina \\ Temple University, USA \\ emilia.zankina@temple.edu \\ https://orcid.org/0000-0003-0312-4095
}

Received: 17. 10. 2019

Accepted: 11. 3. 2020

\section{ABSTRACT}

The article examines public administration reform (PAR) in Bulgaria and the main factors that shaped the reform agenda and dynamics. PAR is examined along five key dimensions - transparency and accountability, civil service and human resources management (HRM), public service delivery and digitalisation, organisation and management of government, and policy-making coordination and implementation. The article argues that there are four main factors influencing reform dynamics and determining policy outcomes in the Bulgarian case: the specific political choices made by government elites, external influence of the EU and of past national legacies, and the importance of institutions and reform mechanisms. To illustrate these factors at work, the article examines three policy initiatives, i.e. e-government, the reduction of administrative burden, and civil service reform. The article presents a longitudinal analysis and a qualitative case-study approach, utilising Annual Reports on the Status of the Public Administration 2001-2018, mapping European Semester Documents 2011-2017, an inventory of PAR initiatives 2005-2018, and interviews of public officials. The pushes for reform have been top-down, externally-driven, and stop-and-go in nature. The results confirm previous findings that Bulgaria is among the EU countries with the poorest record in PAR, struggling to overcome communist legacies and high levels of corruption and politicisation. The Bulgarian case highlights several important lessons: the importance of political will and political dynamics for the outcome of reform efforts; the importance of external pressure and financing; the difficulty of uprooting long-standing legacies in administrative traditions; and the limitations of the top-down approach as an obstacle to the sustainability of reform efforts.

Keywords: public administration reform, Bulgaria, e-government, reduction of administrative burden, civil service 


\section{Introduction}

The article examines public administration reform (PAR) in Bulgaria and the main factors that shaped the reform agenda and dynamics. PAR is examined along five key dimensions - transparency and accountability, civil service and human resources management (HRM), service delivery and digitalization, organization and management of government, and policy-making coordination and implementation. The article argues that there are four main factors influencing reform dynamics and determining policy outcomes: 1) the specific political choices made by government elites; 2) the external influence and the role of the EU, 3) the persisting influence of past legacies, and 4) the importance of institutions and reform mechanism. To illustrate these factors at work, the article examines three policy initiatives - e-government, the reduction of administrative burden, and civil service reform. These initiatives are examined in terms of goals and content, reform outcomes, and lessons learned. They represent a continuum in terms of policy outcomes, with e-government being the most successful, civil service reform being the least successful, and reduction of administrative burden placed in the middle.

The article confirms previous findings that Bulgaria is among the EU countries with the poorest record in PAR and the highest need for improvement in public administration (Thijs et al., 2018, p. 58). The system has encountered great obstacles in overcoming communist legacies and combating high levels of corruption and politicization. The push for reform has been top-down, externally-driven and stop-and-go in nature, with a decreasing commitment on the part of government. The Bulgarian case highlights several important lessons: 1) the importance of political will and political dynamics for the outcome of reform efforts; 2) the importance of external pressure and financing; 3) the difficulty of uprooting long-standing legacies in administrative traditions; and 4) the limitations of the top-down approach which is an obstacle to the sustainability of reform efforts.

The article proceeds with an overview of theoretical approaches to PAR in CEE and an outline of the methodology. tt then summarizes early reform efforts and outlines the five key priorities of PAR in Bulgaria (transparency and accountability, civil service and human resources management (HRM), service delivery and digitalization, organization and management of government, and policy-making coordination and implementation). It further examines the three case studies - e-government, reduction of administrative burden, and civil service. In conclusion, the article aims to tie the lessons learned from the Bulgarian case to the theoretical approaches applied to PAR in CEE and the broader theoretical and empirical significance of the Bulgarian case.

\section{Theory and method}

The study of PAR in Central and Eastern Europe (CEE) provides ample opportunities for gathering new empirical data, testing and expanding theoretical 
knowledge, and enriching the comparative literature. ${ }^{1}$ Several approaches have been applied in examining PAR in CEE in the past three decades. One such approach emphasizes the importance of Historical Institutionalism $(\mathrm{HI})$ (Peters, 1999; Vachudova, 2007). As Meunier and McNamara explain, in their application of HI to European integration (2007, p. 4), institutions shape policy outcomes "rather than simply reflecting the distribution of political power and preferences.... Once in place, [they] can take on a life of their own and contribute to determining and explaining subsequent developments." Despite significant differences, CEE countries all shared a common past under Communism, including Soviet-style administrative systems: highly centralized, with no clear separation between the party and the state apparatus, and with selection for management positions based on a nomenklatura system, which stressed ideological and political loyalty rather than merit (Meyer-Sahling and Veen, 2012). These common administrative traditions and legacies played an important role in shaping civil service reform in CEE (Camyar, 2010; Meyer-Sahling and Yesilkagit, 2011; Meyer-Sahling, 2009), because civil service systems were, in most cases, not created from a clean slate. Rather, they reflected an evolving baggage of norms and beliefs carried from the past that framed and guided future actions. In those cases, reform was slow and difficult because the behavior of civil servants and the newly created institutional mechanisms in CEE were influenced by what was inherited from the Soviet system (Meyer-Sahling and Yesilkagit, 2011; Baker, 2002).

A second, and closely related, concept for understanding the evolution of civil service systems is path dependency. As Järvalt and Randma-Liiv (2010) put it, "[o]nce a specific way for HRM development has been chosen (often on an emergency basis and with limited prior analysis), it is very hard to change it afterwards." CEE countries went through a rapid and to some extent chaotic transition, faced with making major changes in virtually all aspects of their political, economic. Initial decisions about the shape of the civil service were made hurriedly, not necessarily based on a rational analysis of a range of options. But once in place, they created institutions and individuals with vested interests in maintaining them, thus making drastic redirection very unlikely.

Elite studies and political choice further shed light on PAR dynamics. Elite fragmentation and political polarization often led to instability of reform policies. Coalitions and governments changed frequently, and, by the time a set of policy changes reached administrators, a new set of policy changes with drastic shift was put in place by a successor government and sent to administrators (Zankina, 2010). This manipulation of both policies and structures for political ends dampened the positive effects expected from the initial transition reforms (Frye, 2010).

1 This section draws on Ban, C., E. Zankina, and F. Yuldashev. (2012). After Conditionality: Progress or Backsliding in Civil Service Reform in the New Member States of the European Union? Paper presented at the 20 ${ }^{\text {th }}$ annual conference of NISPAcee (Network of Institutes and Schools of Public Administration in Central and Eastern Europe), Ohrid, North Macedonia, 23-26 May 2012. 
A large body of literature examines the role of the EU and conditionality on administrative systems in CEE. The EU used conditionality as an incentive for CEE countries to conform to EU standards (Schimmelfennig and Sedelmeier, 2005). Compared to previous enlargements, EU conditionality for CEE countries was more comprehensive and required administrative capacity to absorb the acquis and to manage EU-supported projects. Not only were CEE countries required to improve the absorptive capacity of the key sectors such as trade, justice, etc., but they also had to meet conditions such as establishing an independent and professional civil service system as well as competition authorities and anti-discrimination commissions (Dimitrova, 2010; Verheijen and Kotchegura, 1999). The European Commission also created manuals that guided the creation of independent civil service systems in CEE countries, which called for civil servants to be recruited based on their professional qualifications and legally protected from politicians (Verheijen and Kotchegura, 1999). At the same time, civil service was not formally part of the acquis, and there was no single document with a standard model of civil service systems that candidate countries were required to adopt. Still, SIGMA's assessments of the state of their civil service systems were based on a common set of standards, and administrative capacity was sometimes mentioned in the EC's annual progress reports. What is particularly interesting about the SIGMA standards is that, while OECD as a whole was strongly supporting New Public Management models across European countries, including pay for performance and greater flexibility for managers, SIGMA was arguing quite the opposite for the new member states. As Meyer-Sahling (2011, p. 240) makes clear, the EU policy "reflects the assumption that the delegation of discretion to managers was not suitable for former communist countries. The legacy of over-politicization and the weakness of the rule of law meant that too early, too much new public management could be a risky choice, leading to unpredictability and even corruption." Thijs and Palaric further affirm that "[e] xperience in Europe in the past two decades shows different administrative reform paths and results, mainly due to different degrees of reform capacity, sustainability of reform approaches, coverage and a 'fitting context" (2018).

The conditionality approach would certainly lead one to believe that conditionality played a very large role in shaping administrative systems in CEE, yet its effect proved to be limited (Epstein and Jacoby, 2014) for several reasons. First, the process of compliance in this area was quite different from that required for policy areas contained in the acquis, which required the aspiring member states to revise their legal codes to harmonize with EU policies and even to put specific administrative structures in place to meet EU standards. The countries of Western Europe did not share a common approach to the structure of civil service, and so the EC relied on the rather vague concept of a European Administrative Space and of a series of standards used by SIGMA in assessing progress (Meyer-Sahling, 2011). Second, the EU based its assessments on formal legislative and institutional changes rather than full implementation, so that in this, as in other areas, such as anti-corruption efforts, reforms "often had merely declaratory character" (Szarek-Mason, 2010, p. 213). Third, by the time accession negotiations began, in many cases adminis- 
trative systems were already in place and dramatic changes in direction were difficult. Lastly, external influence was at times chaotic, with CEE countries sometimes being overwhelmed by a surplus of sources of aid and advice, which were sometimes actively competing with each other and sometimes advocating standard models without much understanding of the specific environment (Ban and Huddleston, 1999). Randma-Liiv (2005) provides a clear sense of the dimensions of such aid in Estonia, listing aid coming from multinational organizations (including the EU and UNDP) as well as a total of 11 bilateral donors.

Scholarship has also focused on post-conditionality and the likelihood of continued progress in civil service reform in CEE. Some scholars expressed concerns about backsliding in the implementation of professional civil service systems after accession and the absence of post-enlargement leverage (Dimitrova, 2010; Epstein and Sedelmeier, 2008; Meyer-Sahling, 2011; Sedelmeier, 2008; World Bank, 2006).

In attempt to answer the main research question, namely what are the key factors shaping PAR in Bulgaria, this article draws on these various theoretical approaches. As Nakrošis argues, administrative reforms in the various CEE countries are the result of complex and dynamic relationships among various factors and, "[d]epending on specific combinations of these factors, countries exhibit a variety of reform trajectories" (2017). I similarly argue that PAR in Bulgaria was influenced by a variety of factors, including past legacies, external influences, specific political choices and institutional mechanisms. Some of those factors were already proved significant in a large comparative study by Kostadinova and Neshkova (2013). What is unique about this study is that it provides a longitudinal analysis utilizing a large amount of qualitative data and providing three detailed case studies to illustrate reform dynamics and outcomes, as well as the interplay of these four main factors. The article builds on research conducted for the EUPACK-Project ${ }^{2}$ - the largest, thus far, initiative to systematically examine and document PAR in all EU28 countries. The article utilizes analysis of the Annual Reports on the Status of the Public Administration 2001-2018, mapping and analysis of European Semester Documents 2011-2017, an inventory of PAR initiatives 2005-2018, and interviews of public officials. ${ }^{3}$ Although all of these documents are publicly available, they have not thus far been examined systematically and combined together to assess PAR in Bulgaria. Qualitative in nature, the article allows us to examine reform priorities, dynamics, and outcomes in the course of two decades and to draw lessons that can be useful beyond the Bulgarian case. Moreover, the article enriches our theoretical and empirical knowledge on PAR in CEE and contributes to an ever growing literature of PAR in the region and in the wider European context.

2 Contract VC/2016/0492 "Support for developing better country knowledge on public administration and institutional capacity building", by the consortium of: The European Institute of Public Administration (The Netherlands), Nick Thijs - project leader, Hertie School of Governance (Germany), Gerhard Hammerschmid - policy expert, Ramboll Management Consulting (Denmark), Karin Attström - Monitoring \& Evaluation Expert. The author was the country expert on Bulgaria

3 All interviewees gave permission to be identified and quoted. 


\section{Overview of early reform efforts}

According to a recent comparative study, Bulgaria is among the EU countries with the highest need for improvement in public administration (Thijs et al., 2018, p. 58). Bulgaria remained under the Cooperation and Verification Mechanism (CVM) for over twelve years after accession. Although the most recent report (European Commission, 2019), finds significant improvement in all recommendations related to public administration, including the role of internal inspectorates, public procurement procedures, and mechanisms for dealing both with high-level and petty corruption in the public sector, and the Commission suggested terminating the CVM mechanism for Bulgaria, it clearly outlined the need for continued improvement and monitoring both internally and externally. ${ }^{4}$

The Bulgarian public administration is characterized as belonging to the East European tradition (Kullmann and Wollmann, 2014), the South-Eastern tradition (Demmke and Moilanen, 2010) and the Balkan tradition (Eurostat Academic Study, 2010). These various classifications emphasize two main features of the Bulgarian public sector - its Ottoman legacy that translates into inefficiency and a high level of corruption, and its communist legacy that translates into highly centralized system, strong control of the former nomenklatura, and a great degree of politicization (Zankina, 2018, p. 82). These administrative traditions and legacies played an important role in shaping public administration reform (Camyar, 2010; Meyer-Sahling and Yesilkagit, 2011; Meyer-Sahling, 2009), as new systems were influenced by the Soviet system (Meyer-Sahling and Yesilkagit, 2011; Baker, 2002).

Political instability and economic downturn during the early transition period pushed back reform of the public administration in the list of priorities not only in Bulgaria, but in several post-communist countries, leaving administrative systems largely intact (Baker, 1994). Administrative reform was closely linked to success in the democratic and economic transition. Thus, countries where opposition forces managed to oust former communist leaders and implement reform programs early on, also had a greater chance in reforming their public administrations (Meyer-Sahling, 2004).

In Bulgaria, the strong political position of the former communist party hindered impetus for reform, as party cadres and the nomenklatura coalesced in attempt to "survive" under the new conditions (Verheijen, 1999, p. 96). Little progress was made in the early years of the transition and PAR did not become a priority until the late 1990's when a severe financial and banking crisis toppled the socialist government and a new government of the United Democratic Forces (UnDF) came to power in 1997, completely reorienting the country towards the Euro-Atlantic structures. Desire to join the EU and NATO became the main driver behind reform of the public administration (Ellison, 2007, p. 227). Following the EU SIGMA guidelines for reform of the public

4 European Commission (2018), "Report from the Commission to the European Parliament and Council on Progress in Bulgaria under the Cooperation and Verification Mechanism", Available at: https://ec.europa.eu/info/sites/info/files/progress-report-bulgaria-com-2018-850_en.pdf. 
administration, the UnDF government developed a Strategy for the Modernization of Public Administration (1998), set up a Ministry of Public Administration and adopted the State Administrative Law in 1998 and the Law on Civil Service in 1999. By 2000, the Institute for Public Administration and European Integration (IPAEI) and the Council for Coordinating the Implementation of Integrated Administrative Service were established. The subsequent government of Simeon Saxecoburggotski and his party the National Movement Simeon II (NDSV) continued with reform efforts putting emphasis on civil service training, performance evaluation, service delivery and one-stop shops, and e-government. A major milestone were the Public Procurement Law adopted and the Law for Limiting Administrative Regulation and Administrative Control of Economic Activity. These developments were in sharp contrast to the previous lack of reform and were positively noted by the EU commission. Consequently, Bulgaria was invited to sign the EU accession agreement in 2004, with an accession date of January 2007. EU conditionality and the ability of the EU to tie both membership and funding to the success (or failure) of reform efforts served as key drivers. Overall, the pre-accession process had a very positive effect on the professionalization of the civil service, since the public administration was heavily involved in the pre-accession phase and increasingly responsible for priority setting (Borissova, 1999, p. 3). Interviews with public officials indicate this was the most exciting time in their career as they had the ability to learn best practices from their European counterparts and actively participate in the transposition of EU laws and the establishment of new structures (Ban et al., 2012).

While the UnDF (1997-2001) and NDSV (2001-2005) governments were instrumental in setting the foundations of public administration reform, subsequent governments proved far less committed to continuing reform efforts. As stated in the Excellence in Public Administration Report (Pitlik et al., 2012), "Bulgaria performs significantly below the EU-average as measured by the World Bank's government effectiveness indicator, which provides an assessment of the quality of public administration in a broad sense. Hence, perceptions of the quality of public services, the quality of policy formulation, the implementation of policy and the credibility of public servants' commitment to such policies are considerably worse than the EU-average. In addition, Bulgaria's scores have remained virtually unchanged since 2006." In addition, PAR has become increasingly dependent on EU funds (see Tables 1 and 2). While Bulgaria was a champion in the transposition of EU law, with a transposition deficit of $0 \%$ in 2008 (Trauner, 2009), implementation was a serious problem. CVM reports were consistently critical on all counts, with particular emphasis on corruption. High level political corruption and ties between the state apparatus and private interests proved a persistent problem that undermined the already weak trust in government institutions and harmed the business climate in the country, hampering economic growth (Trauner, 2009, p. 7). Stanishev's government (2005-2005) was harshly criticized for fraud and corruption. OLAF carried out a series of audits in 2008, revealing mismanagement and corruption on a serious scale. The revelations pointed to misuse of funds under the SAPARD, PHARE, and ISPA programmes and resulted in the 
Freezing of over $€ 800$ million of EU funds in 2008. This made Bulgaria the first EU member state to lose EU funds due to misuse (Trauner, 2009, p. 10).

Table 1: Administrative Capacity Projects Funded by the National Budget

\begin{tabular}{|cccccc} 
& $\begin{array}{c}\text { Central } \\
\text { Administration }\end{array}$ & $\begin{array}{c}\text { Territorial } \\
\text { Administrations }\end{array}$ & $\begin{array}{c}\text { Total } \\
\text { Administrations }\end{array}$ & $\begin{array}{c}\text { Total } \\
\text { Projects }\end{array}$ & $\begin{array}{c}\text { Total } \\
\text { funds BGN }\end{array}$ \\
\hline $\mathbf{2 0 0 9}$ & 8 & 15 & 23 & 30 & $86,699,495$ \\
\hline $\mathbf{2 0 1 0}$ & 4 & 10 & 14 & 34 & $59,198,490$ \\
\hline $\mathbf{2 0 1 1}$ & 5 & 10 & 15 & 22 & $59,085,840$ \\
\hline $\mathbf{2 0 1 2}$ & 9 & 22 & 31 & 72 & $52,013,532$ \\
$\mathbf{2 0 1 3}$ & 7 & 21 & 28 & 71 & $17,600,000$ \\
\hline $\mathbf{2 0 1 4}$ & 7 & 10 & 17 & 48 & $24,044,009$ \\
\hline $\mathbf{2 0 1 5}$ & 4 & 12 & 16 & 24 & $5,265,733$ \\
\hline
\end{tabular}

Source: State Administration Reports available at: <http://www.strategy.bg/ Publications/View.aspx?lang=bg-BG\&categoryld=\&ld=81\&y=\&m=\&d=>.

Table 2: Administrative Capacity Projects Funded by the EU (mainly OPAC) or Other Foreign Donors

\begin{tabular}{|cccccc} 
& $\begin{array}{c}\text { Central } \\
\text { Administration }\end{array}$ & $\begin{array}{c}\text { Territorial } \\
\text { Administrations }\end{array}$ & $\begin{array}{c}\text { Total } \\
\text { Administrations }\end{array}$ & $\begin{array}{c}\text { Total } \\
\text { Projects }\end{array}$ & $\begin{array}{c}\text { Total } \\
\text { funds BGN }\end{array}$ \\
\hline $\mathbf{2 0 0 9}$ & -- & -- & 90 & 107 & $208,53,955$ \\
\hline $\mathbf{2 0 1 0}$ & -- & -- & 181 & 499 & $29,827,655$ \\
\hline $\mathbf{2 0 1 1}$ & 38 & 66 & 104 & 319 & $51,507,051$ \\
\hline $\mathbf{2 0 1 2}$ & 53 & 160 & 213 & -- & $59,085,840$ \\
\hline $\mathbf{2 0 1 3}$ & 36 & 180 & 216 & -- & $128,000,000$ \\
\hline $\mathbf{2 0 1 4}$ & 60 & 257 & 317 & 787 & $162,392,311$ \\
\hline $\mathbf{2 0 1 5}$ & 55 & 143 & 198 & 326 & $190,959,506$ \\
\hline
\end{tabular}

Source: State Administration Reports available at: <http://www.strategy.bg/

Publications/View.aspx?lang=bg-BG\&categoryld=\&ld=81\&y=\&m=\&d=>.

The main achievement of the Stanishev government was the start of the Operational Program on Administrative Capacity 2007-2013 (OPAC), financed by the European Social Fund and the national budget. A milestone in public administration reform, OPAC aimed to improve the relationship between the administration and citizens by optimizing the structures of the central, district and municipal administration, focusing on four priority axes - good governance, human resource management, service delivery and e-government, and technical assistance. The subsequent government of Borisov and his party, Citizens for European Development (GERB), put great emphasis on anti-corruption efforts by passing legislation and setting up new administrative bod- 
ies to fight corruption. At the same time, Borisov closed the Ministry of Public Administration and Reform, signaling deprioritization of PAR.

\section{Key priorities of the reform agenda}

The key priorities in PAR as initially outlined in the 2003-2006 Strategy and reconfirmed in subsequent strategies include transparency and accountability, human resource management and civil service training, service delivery and e-government, and, as of later years, decentralization. Each of those are reviewed below.

\subsection{Transparency and accountability}

Corruption has been a persistent and serious problem in Bulgaria, as reiterated in all CVM reports. It has been the main focus of government policy in the last decade with emphasis on anti-corruption efforts, transparency, and accountability. Despite such focus, the fight against corruption was highlighted in the January 2017 CVM report as the area where least progress had been made in Bulgaria over the ten years of the CVM.

The foundations for observing the principles of transparency and accountability are embedded in a legal framework such as 1) the State Administration Law (1998) mandating the creation of inspectorates in every ministry and allowing citizens to file complaints; 2) the Access to Public Information Law (2000), which along with the digitization of the public administration provides access to information, including through specially designated portals; 3 ) the Ombudsman Law (2003), and its later amendment linking the Ombudsman to municipal administrations, in addition to the central administration; and 4) the Public Procurement Law (2004), which has been amended multiple times and is based on the principles of competition, transparency, equality, and non-discrimination.

Most recent initiatives have been focused on high-level corruption. One set of initiatives concerns illegal property as addressed in the Law for the Expropriation of Property Acquired through Criminal Activity (2005) and the Commission for the Identification of Property Acquired through Criminal Activity (2005), and subsequent amendments. Another set is related to the prevention of conflict of interest with the Conflict of Interest Law adopted in 2009, the Commission for the Prevention and Identification of Conflict of Interest established in 2011, and the National Strategy for Public Procurement in Bulgaria adopted in 2014. The greatest emphasis has been placed on countering corruption with numerous initiatives by each government. The most recent anti-corruption law adopted in 2018 set up a unified body to coordinate anti-corruption efforts. However, questionable clauses in the law that infringe on individual freedoms and the presumption of innocence, as well as public scandals involving high-rank anti-corruption officials have resulted in a public outcry. 
Some positive developments include mandatory regulatory assessment of normative acts and mandatory public consultation, the Open Data Bulgaria providing a unified registry of electronic databases of various government structures, and strengthened administrative control with mandatory reporting requirements.

Overall, Bulgaria's track record on improving transparency and accountability has been mixed. Measures countering corruption have had dubious results. According to Transparency International's Corruption Perception Index (CPI), Bulgaria scores 41 out of 100, ranking 69 out of 168 . Control of corruption is in the $52 \%$ percentile rank and the Open Budget Index gives Bulgaria a score of 56 (Transparency International). More importantly, control of corruption has not improved, but in fact has decreased in recent years. Bulgaria continues to rank the highest in the EU in terms of perceived level of corruption and corruption is considered the main obstacle to doing business in the country. As stated in the 2016 CVM report, the institutional framework for fighting corruption is "fragmented, uncoordinated, and unequal to the challenge" (European Commission, 2016). Anti-corruption efforts in Bulgaria are characterized by lack of political will and sustained strategy, fragmented institutional framework, and poor implementation record. High-level corruption is particularly problematic, especially at the last stage of convicting government officials. Improvements in the monitoring, identification, and exposure of corrupt practices have been undermined by the unwillingness or inability of courts to prosecute political figures. Continuous criticisms in CVM reports have failed to bring about political will and compliance. There have been some positive changes at the institutional level, with improvements in the normative and legal framework and increased transparency as a result of e-government initiatives and open data. Overall, progress in these areas is reactive (to EU recommendations) and externally-driven, disruptive, and behind track.

\subsection{Civil service and HRM}

Civil service reform constitutes a major part of Public Administration Reform. The key priorities in reform efforts have been introducing a merit-based system and limiting politicization. The strategy for achieving these goals entails implementing a comprehensive human resource management system that includes evaluation systems and performance pay, mechanisms of recruitment and motivation, civil service trainings, etc. A detailed account of civil service reform follows in section 7 .

\subsection{Service delivery and digitization}

Improving the quality of services and introducing e-government has been a key priority in public administration reform set by the Kostov and NDSV's governments and pursued by subsequent governments. The foundations for reform in that area were laid in the Law on Public Service Delivery to Natural and Legal Persons (1999) and the Strategy for E-government (2002). One of the first steps was establishing a Coordination Center for Information, Com- 
munication, and Management Technologies (CCICMT) in 2002. In 2006, the Administrative-procedural code was adopted, regulating service delivery, establishing unified procedures for legal and private persons, and rules for judicial control of administrative acts. An Administrative Service Self-evaluation System was also adopted in 2006, which allows for annual reporting and monitoring of all administrative units. An Information System for Regional Statistics with the National Statistical Institute was set up in 2006, providing for better monitoring and public access to information of territorial units. The E-governance Law was adopted in 2007, introducing mechanisms for onetime entry multiple-use data. In the same year, the List of Unified Labels of Administrative Services was adopted.

The main initiative in this area has been OPAC's Priority Axis III on Service Delivery and E-government starting in 2007. The program achieved $67.7 \%$ completion rate of financial implementation as of 2014. One-stop-shop services, a key strategic priority, were adopted only in 15\% of administrative units, while $25 \%$ of administrative units use Quality Management Systems. Document Management Systems were adopted in all units, and 2,540 services are currently offered online, with $98 \%$ of administrative units delivering services within the legal deadline (OPAC, 2015). In 2014, one-shop services were replaced by a new project for the introduction of Complex Administrative Service which aims to further improve service delivery. Some problems still remain. As stated in the Integrated Service Delivery Model of 2013, administrative service delivery has achieved integration only within the given administration, with no cooperation between different administrations. Moreover, services are frequently delivered at inconvenient locations, requiring travel to the capital or the regional center (Thijs and Mackie, 2016).

Some other initiatives include: the Plan for the Optimization of the Public Administration 2010-2011, with emphasis on improving service delivery; the Good Governance Program 2010-2013, focused on improving the business climate; the adoption of a Unified Electronic Communication Network in 2011; the Comprehensive Strategy for E-government in Bulgaria 2011-2015, focused on integrated management of IT resources; the Basic Model of Complex Service Delivery adopted in 2013 (part of OPAC), implementation started in 2014, with expected completion envisioned within the Strategy for the Development of the Public Administration 2014-2020 ; the Strategy for the Development of E-government 2014-2020 with updated goals and priorities, and the National Plan for Reducing the Administrative Burden of the Business 2010 - 2017, adopted in 2010 and updated in 2012 and 2015. Important developments in e-government are examined in section 4.

\subsection{Organization and management of government}

The key problem in the organization and management of government has been the high level of institutional instability and frequent restructuring of government units. Major restructuring of the central administration and ministries is observed with every change of government, due to the legal provi- 
sion allowing each government to open, close or reorganize ministries and agencies. In addition, changes in the organizational rules of administrative units allow for under the radar restructuring that does not require approval by parliament and personnel changes. Such instability and restructuring have solidified a long tradition of politicization of the public administration and have undermined efforts for improving the quality of services. Despite reform efforts, politicization remains a major problem in Bulgaria and is much higher than in many other EU countries (Zankina, 2016).

The main priorities in the organization and management of government have been decentralization and good governance. The foundations of the organization of government were set up in the Local Self-Government Act (1991), the Local Administration Act (1991), and the State Administrative Law (1998), all amended numerous times in the last 20 years. The 2006 amendments to the State Administrative Law introduced annual reporting and yearly goals for each administrative unit, an administrative registry, and strengthening of the inspectorates. The main initiative in this area has been the OPAC Priority Axis I "Good Governance" program. As of 2014, the program had achieved $88 \%$ completion rate in this priority axis, with a third of the administrative units introducing optimization procedures, over a third introducing monitoring regulations, and a quarter having completed functional analyses as of 2015 (OPAC, 2015). A major setback in the organization of government and public administration reform has been the closing of the Ministry of Public Administration and Reform in 2009 and its replacement with an advisory council.

More positive recent developments include the Strategy for the Development of Public Administration 2014-2020, with key strategic goals of effective governance and rule of law, public-private partnership governance, open and responsible governance, professional and expert governance; District Administration Strategies 2014 - 2020, containing good governance and civil service objectives at the district scale; Plans for Municipality Development 2014 - 2020, containing good governance and civil services objectives at the municipality scale; and the establishment of Governance Decentralization Council in 2013.

An updated Strategy for Decentralization adopted in 2016 is emphasizing the transferring of authority to local governments, achieving an optimal distribution of resources between central and local government, citizen control over public institutions, and greater influence of regional authorities in policy coordination. The goals of the strategy in the first period (2006-2009) and the second period (2010-2013) were largely unachieved - under $40 \%$ of all measures were achieved. The major problem was refusal of the central government to allow financial autonomy of the municipalities. At the same time, we have seen a reduction in size of the central administration, coupled with an increase in size of territorial administrations. Another major issue is also the financial autonomy of local government and the continued dependency on the central government. Local governance in Bulgaria is experiencing steady deterioration especially in terms of financial health as the level of indebtedness 
and consequently the dependency of local authorities on the central government and the subsidies from the state budget increase. Progress in this area can be characterized as top-down, disruptive and highly differentiated based on the sector and geographic location.

\subsection{Policy making, coordination and implementation}

Implementation and coordination have been a great challenge in the Bulgarian context. While we notice an excellent record in transposing EU legislation and a large volume of strategies adopted in every area, implementation lags seriously behind. Institutional instability contributes to a fragmented institutional framework, characterized by lack of coordinated and integrated operational structures. The first step forward in policy coordination was made with Kostov's Strategy for Administrative Modernization that identified the clear distribution of responsibilities at the different levels of the executive and unification of the structure as key goals. The NDSV government continued to work in this direction in an attempt to improve policy coordination and functionality, eliminating double-functions and functions atypical for government, and identifying gaps. Such goals have been embedded in subsequent government strategies, yet, problems persist. Mechanisms of policy formulation have been established, including public consultations and input from various stakeholders. However, not enough attention and time are given to implementation and evaluation. As identified in earlier studies (Shoylekova, 2007), policy formulation is dominated by the ruling majority, the role and input at the political level (particularly the ministers and their political cabinets) are not well-defined, and policy phases are not well synchronized. In this area, as well as in all others, the EU has been the main driver of reform and of financial support through its structural and investment funds. A major problem has been the misuse of EU funds and the failure to absorb allocated funds. Sanctions on the part of EU included freezing of a large amount of funds in 2008, following OLAF investigations, as well as smaller financial sanctions.

Some of the initiatives in this area include the strategies for decentralization (2006) aimed at improving territorial governance and coordination between government levels and facilitating public participation in local governance., the National Strategic Reference Framework 2007 - 2013 that aims at balanced territorial governance, the Convergence Program aligned with EU strategy "Europe 2020". Overall, policy-making, implementation, and coordination are the most problematic areas after corruption. Improvements in other areas have failed to improve policy-making capacity. Lack of coordination, doubling of functions, frequent change of governments and policy priorities have hindered progress. Progress in this area can be characterized as disruptive, top-down, and stagnating.

\section{E-government}

E-government is one of the most successful reform initiatives in the context of public administration reform in Bulgaria. As such, it has witnessed the most 
progress and the least political resistance. E-government has been a key priority for every government since 1997 and each government has registered a list of initiatives and accomplishments. E-governance is seen as an instrument to reduce corruption, improve the business environment, improve efficiency, and provide a channel for inclusion of citizens and non-governmental actors in decision-making. It is a priority that has been largely funded externally, primarily through the OPAC and the Good Governance programs. Although there has been continuous improvement in the quality and scope of e-services, progress has been slow and far behind track compared to other new EU member states. There has been constant change and re-alignment in e-government strategies, as well as delayed implementation and large, inefficient spending.

E-government first appeared on the agenda in 1997 with Kostov's government. After establishing a Ministry of Public Administration and Reform in 1997, the government launched a number of e-government initiatives, including an IT investment project, a website of the Council of Ministers, a Registry of Administrative Services, a Registry of Public Procurement, a Registry of Civil Servants, a public administration portal, and discussion forums. These first initiatives costed \$5 million, with another \$22 million budgeted for completing the reform. ${ }^{5}$ The subsequent NDSV government continued work on public administration reform and e-government, adopting the first E-government strategy in 2002, establishing a basic infrastructure and a coordination center, and introducing the first e-services. ${ }^{6} \mathrm{~A}$ management monitoring system was introduced to track the implementation of e-government, ${ }^{7}$ electronic signatures were first introduced in some ministries, and a comprehensive i-Bulgaria project was launched. ${ }^{8}$

The start of the Operational Program on Administrative Capacity 2007-2013 (OPAC) during the tenure of the Stanishev government was a milestone in PAR and e-government. OPAC financing combined with the efforts of the Minister of Public Administration and Reform, Nikolay Vassilev, provided the necessary driver for reform both in terms of resources and political will. Vassilev aligned priorities with the e-Europe objective to deliver 20 administrative services, introduced legislative changes and launched a number of initiatives such as, the e-Justice project with a total cost of BGN 6 million, ${ }^{9}$ a Unified Trade Registry with a total cost over BGN 4 million (almost entirely financed by the World Bank), an Integrated e-Government System, an Integrated e-Municipality Sys-

52001 Annual Administrative Report. Available at: http://www.strategy.bg/Publications/View. aspx?ld=81.

6 Those included change of address, judicial registry of companies and physical persons, social security payments of individuals, and company contributions to the social security system. 2002 Annual Administrative Report: Available at: http://www.strategy.bg/Publications/View. aspx?Id=81.

72003 Annual Administratrive Report. Available at: http://www.strategy.bg/Publications/View. aspx?ld=81.

8 The program included 5 initiatives for schools (i-class), universities (i-university), research institutes (i-net), as well as an i-Center to facilitate access to internet and electronic services in small towns and villages2004 Annual Administrative Report. Available at: http://www. strategy.bg/Publications/View.aspx?Id=81.

92006 Annual Administrative Report. Available at: http://www.strategy.bg/Publications/View aspx?ld=81. 
tem, an electronic health portal, ${ }^{10}$ as well as OPAC funded projects such as an e-Payment system. The most significant step of the Stanishev government was the adoption of the E-Government Law in 2007 which provided the legal framework for transitioning from e-government to e-governance.

With the closing of the Ministry of Public Administration and Reform in 2009, e-government was transferred to the Ministry of Transport, Information Technologies and Communications. In 2011, the government adopted a Comprehensive Strategy for E-government in Bulgaria ${ }^{11}$ and established the E-Governance Council. Both were modeled after the Estonian model of e-governance. ${ }^{12}$ Other initiatives include, the "Integrated administrative service and the central and local level", the Unified environment for exchange of e-documents (UEEED), the Unified Electronic Communication Network, the e-document exchange system, as well as two large OPAC projects - "Development of the administrative service by electronic means" (BGN 18 million) and "Improving Administrative Services through Developing Centralized E-government Systems" (BGN 12 million)..$^{13}$ A major initiative was the launching of the Bulgarian open data portal in September 2014 - a collaboration project between the Council of Ministers and an NGO aiming to facilitate access to electronic resources, increase the use of e-services, and inform citizens of government actions. Subsequent efforts included roadmaps for e-justice and e-customs, a strategy for the integrated electronic communication network, and a project for optimizing the EU funds 2020 system. In 2016, the E-government Council was transformed into the State Agency "E-Governance", a new law on Electronic Identification was adopted, along with a strategy and roadmap for Developing E-Governance 2016-2020. ${ }^{14}$ The most recent project by the State Agency "E-government" is to carry out an inventory check of the IT infrastructure, with the goal of creating a registry of e-services, with a total cost of BGN 2.5 million.

Although e-government was a priority for all governments and a number of positive developments took place, there was delay in implementation, insufficient progress, and lack of coordination and strategic approach. According to the 2016 European semester documents, the slow implementation of reforms in the areas of public administration and e-government prevent significant improvements in the business environment. Some of the key obstacles in e-government have been:

10 The health portal was completed in 2007, servicing 40,000 civil servants.2007 Annual Administrative Report. Available at: http://www.strategy.bg/Publications/View.aspx?ld=81.

11 The strategy focused on integrated management of IT resources and stressed the importance of service to the public, business and the administration, partnerships at national and international levels effectiveness and efficiency, 24/7 access, equal access to e-services, transparency and accountability. Comprehensive Strategy for Eg0government 2011-2015. Available at: http://www.strategy.bg/StrategicDocuments/View.aspx?lang=bg-BG\&ld=662.

12 Comprehensive Strategy for Eg0government 2011-2015. Available at: http://www.strategy. bg/StrategicDocuments/View.aspx?lang=bg-BG\&ld=662.

132011 Annual Administrative Report. Available at: http://www.strategy.bg/Publications/View. aspx?ld=81.

14 The key priorities of the strategy are implementing electronic identification, transition to hybrid cloud infrastructure, and a pilot project for electronic distance voting. E-governance report 2016. Available at: https://e-administration-report.eu/. 
- Lack of political will at the local level, especially in the early stages of the reform. There was a lot of resistance from territorial administrations and municipalities who feared e-government would lead to cutting positions and reducing the size of the administration.

- Lack of financial resources. Although most of the projects in e-government are funded or co-funded externally, resources have been scarce and insufficient for building and maintaining IT infrastructures and training civil servants. At the same time, there have been accusations in the media that too much money was spent on e-government with limited results. The latest scandal with hacking large amounts of data on citizens and businesses from the National Revenue Agency is a case in point.

- Lack of qualified civil servants - a persisting problem throughout the public administration. Turnover is high, young people are hard to attract, long-serving cadres are hard to train.

- Lack of technical resources. Computers are old, operation systems are not frequently renewed, software licenses are not available in sufficient numbers.

- Lack of a clear strategy, sound management, and coordination, especially at the local level. There is often confusion as to what are the priorities, who is responsible, and what are the expected results. There is no cascading down of strategic priorities at the national level and no bottom-up processes for defining and implementing strategies.

- Lack of motivation by the leadership and the lower levels to implement e-government. Aversion to using new systems, tokenism, and resistance, failure to see the need and the benefits of e-government lead to an apathetic attitude towards e-government reform.

A recent study by the Bulgarian Industrial Association compares e-government reform in Bulgaria and Estonia. ${ }^{15}$ According to the study based on official Eurostat and World Bank reports, Bulgaria has spent around $€ 2$ billion on e-government between 2002-2016. The public administration offers a total of 2,900 e-services, $87 \%$ of which primary and only $13 \%$ complex. By comparison, in Estonia there are over 900 electronic systems offering over 5,000 electronic services, most of which complex. Only $19 \%$ of the public administrations in Bulgaria offer e-services and only $12 \%$ maintain specialized registries for offering e-services, $27 \%$ of administrative registries are paper-based only, $3 \%$ of administrative structures do not accept electronically signed documents, and $98 \%$ of e-service requests are for five administrative agencies - the Registry Agency, Agency for Geodesy, Cartography and Cadastre, the National Revenue Agency, the General Labor Inspectorate Executive Agency, and the Agency for Vocational Education and Training. Only 19\% of Bulgarian citizens have used online government services in the past 12 months, compared to $77 \%$ in Esto-

15 “СТИГА ВЕЧЕ!" 18: ЕЛЕКТРОННО ПРАВИТЕЛСТВО (БЪЛГАРИЯ - ЕСТОНИЯ) [That is Enough 18: E-government (Bulgaria-Estonia)], Bulgarian Industrial Association, December 2, 2017, https://www.bia-bg.com/news/view/23682/. The study is based on the Annual Reports on the State of the Public Administration, Eurostat and World Bank data. A detailed list of all sources can be found at the provided url. 
nia. The report has triggered a heated political debate, a change of the director of the State Agency E-Government, and an additional accusation in one of the non-confidence votes in parliament against the Borisov III cabinet.

A look at a particular e-government initiative confirms such findings. E-healthcare was launched in Bulgaria in 2007. A report of the Bulgarian National Audit Office declares e-healthcare reform a complete failure. ${ }^{16}$ Despite commitment by every government in the last decade to e-healthcare, Bulgaria does not have an integrated health-information system and does not meet the requirements for trans-border health information exchange. Bulgaria is Far behind other EU countries in e-healthcare and data exchange between the various information systems and registries in the countries remains a major challenge. There is no comprehensive digital medical record of patients and no national health portal, offering a one-stop shop for health services and information. Only $9 \%$ of patients have used e-healthcare, while $47 \%$ are aware of the existence of e-healthcare.

Such criticisms notwithstanding, Bulgaria has an ever-improving e-government system. Some of the key elements in this system include systems and portals that can be grouped in three categories: 1) providing services to the citizens and business; 2) transparency and accountability - providing information on government initiatives, decisions, budgets, funds, etc., 3) providing mechanisms of inclusion of citizens in decision-making.

There are several lessons to be learned from the Bulgarian case:

- The importance of coordination and collaboration between the central and local levels of government. The Bulgarian case shows that political will at the central level does not translate into support and implementation at the local level. It also shows that some of the problems at the local level, namely overdependence on financing by the central budget, lack of resources for local-level initiatives, lack of investment, innovation, and entrepreneurship, can impede specific projects and e-government in particular. The municipalities who have been most successful in implementing e-government have been the largest and the wealthiest or those not financially dependent on the central government.

- The external influence of the EU, EU funding, and the wider EU-context in terms of strategic direction and best practices have both provided the blue print for reform and secured political consensus at the top level. The question, however, is why the presence of these factors has not had such a positive influence in some other areas such as civil service reform for example. One explanation may be that civil service systems within the EU vary greatly, whereas e-government being relatively new is not entrenched in past practices and path dependency and therefore is easier to transpose.

16 “10-годишен провал на електронното здравеопазване установи одит на Сметната палата' [10year failure of e-healthcare reported following an audit by the Audit Office], Bulgarian National Audit Office, September 28, 2017, http://www.bulnao.government.bg/bg/articles/10-godishen-proval-na-elektronnoto-zdraveopazvane-ustanovi-odit-na-smetnata-palata-1782. 
- Administrative capacity is a major problem. E-government requires a certain minimum of human and material resources. The low salaries of civil servants in Bulgaria, the under-resourced units and the low-quality material base create a vicious circle that perpetuates the lack of quality cadres and lack of innovation and initiative. Although Bulgaria ranks high in terms of innovation, this applies only to the private sector, while the public sector remains hungry for quality people and for creative solutions. Another element is the lack of public-private partnerships (there are a few as of recently) that can transfer knowledge from the private sector and assure a mutually beneficial collaboration. Such public-private partnership can speed up reform efforts, improve quality, and reduce cost.

\section{Reducing administrative burden}

The reforms aimed at reducing the administrative burden have been characterized by steady and continuous progress aligned with EU priorities and the Action Programme for Reducing Administrative Burdens in the EU (ABR Action Programme). The main driver for reform in the early years was EU membership. The external influence and financial support by the EU has been crucial for jumpstarting and implementing reforms in that area. The OPAC and "Good Governance" programs have been key funding sources for programs aimed at reducing the administrative burden. The indefinitely extended CVM mechanism further plays an important disciplining role. The goals of the reform are improving the business climate, attracting FDI, improving effectiveness and efficiency of the public administration, and increasing transparency. Several mechanisms have been adopted in this area -1 ) reducing the number and scope of regulatory regimes, and transposing EU regulatory regimes, 2) improving service delivery, including establishing one-stop shops, establishing once only principle of information collection and mandatory information exchange, computerizing services, integration and standardization of processes and procedures, 3) reducing cost to citizens and business through reduction of documents and time required, reduction of information obligations, reduction of taxes and fees, 4) improving access to information to citizens and business through registries, websites, electronic alerts, 5) including citizens and businesses in decision-making through consultation portals and feedback mechanisms.

The reform initiative has enjoyed political support by all governments since its start in 2001-2003. At the same time, there are some tensions within the administration, between central and local authorities, and among political parties, as well as discontent by business organizations. Such tensions are fueled by fears of personnel cuts as a result of improved efficiency and digitization of processes, ${ }^{17}$ accusations of mismanagement and overspending, ${ }^{18}$ disagree-

17 „Споделените услуги ще заместят част от чиновниците до 2018 г.“" [Shared services will preplace civil servants by 2018], Capital.bg, September 25, 2017, https://www.capital.bg/politika_i_ikonomika/bulgaria/2017/09/25/3047926_spodelenite_uslugi_shte_zamestiat_chast_ ot/.

18 „Депутатите бистрят: е-управление, колко пари са отишли..." [MPs are debated over e-government, how much was spent.....], Dnes.bg, January 19, 2018, https://www.dnes.bg/ politika/2018/01/19/deputatite-bistriat-e-upravlenie-kolko-pari-sa-otishli.365540. 
ment and lack of coordination between central and local administrations, ${ }^{19}$ and continued criticisms by business. ${ }^{20}$

The reform has been characterized by continuity with three action plans building one onto the next. There has been great emphasis on the legal framework. The main challenges have been in coordinating efforts among various administrative units, and particularly among the central and local administrations. Implementation at the local level has been slower and harder. The delay in e-government implementation has been an obstacle, given the close link between e-government and improved service delivery. Changes in institutional structures, and, in particular, the bodies overseeing the administrative reform, have further impeded progress.

The reduction of the administrative burden is embedded in the strategic objectives of the Operational Programs "Administrative Capacity" and "Good Governance". ${ }^{21}$ Reducing the administrative burden for citizens and business first appeared on the agenda in 2001, yet, no progress was registered in $2001{ }^{22}$ It became top priority in 2003 with the adoption of the Law for Limiting Administrative Regulation and Administrative Control on Economic Activity (Llaracea). ${ }^{23}$ One stop shops became mandatory in 2006, yet, at the time, $96.7 \%$ of administrative units reported they have not adopted any normative acts aimed at reducing the administrative burden. ${ }^{24}$ In 2007, the Ministry started a Better Regulation Program as part of the European Commission's Program "Better Regulations, Growth, and Employment". In the same year, the Ministry of Economy partnered with the World Bank to develop a regulatory strategy for Bulgaria that envisioned a unit to oversee public administration reform, civil servant trainings in "better regulation", completing the administrative registry, collaborating with local government on improving regulatory regimes, and establishing Regulatory Impact Assessment (RIA). The adoption of the Better Regulation Program 2008-2010 became the cornerstone of regulatory reform. As part of this program, the Better Regulation Unit (BRU) at the Council of Ministers (CoM) was established in 2008, followed by a training program for administrative personnel and preparation of regulatory impact as-

19 „Спешни мерки за намаляване на административната тежест за гражданите и бизнеса обяви държавата" [The State announced Urgent Measures for Reducing the Administrative Burden], Bnr.bg, June 16, 2017, http://bnr.bg/post/100842770/vlasti-i-institucii-obsajdat-pri-borisov-namalavaneto-na-administrativnata-tejest-i-oblekchavaneto-na-rabotata-s-grajdani.

20 „Тромави процедури гонят инвеститори в строителството от България“ \{Clumsy pгосеdures chase away construction investors from Bulgaria], Ivenstor.bg, October 2, 107, https:// www.investor.bg/bylgariia/451/a/tromavi-proceduri-goniat-investitori-v-stroitelstvoto-ot-bylgariia--247625/.

21 Atanassov, A. et al., "Assessment of the Administrative Burdens for Businesses in Bulgaria According to the National Legislation Related to the European Union Internal Market," Journal of Contemporary Management Issues, Vol. 22, 2017, Special issue, pp. 21-49.

222001 Annual Administrative Report. Available at: http://www.strategy.bg/Publications/View. aspx?ld=81.

23 The law settles the regulation of economic activity, sets up the framework of administrative control, and defines the various regulatory regimes. "Better Regulation for Higher Growth: Bulgaria's Business Regulations - Achievements and Regulations," World Bank, October 2010, Voll.

242006 Annual Administrative Report. Available at: http://www.strategy.bg/Publications/View. aspx?ld=81. 
sessments of important legislation. ${ }^{25}$ By the end of the mandate of the Stanishev government, 149 administrative units reported adopted measures aimed at reducing the administrative burden, 6 regulatory regimes were removed out of the 16 envisioned by the Better Regulation Program, and 100 municipalities reduced regulatory regimes at the municipal level. ${ }^{26}$ The Administrative Service Self-Evaluation System established in 2006 became the main tool for monitoring and evaluating the quality of administrative service, including measures to reduce the administrative burden. In 2010, the first Borisov cabinet adopted an Action Plan for Achieving the National Target for Reducing Administrative Burdens by $20 \%$ by 2012 . The plan envisioned 135 measures of eliminating or reducing regulatory regimes, with a main focus on removing information obligations on business. With the adoption of the plan, Bulgaria completed the first stage of the ABR Action Programme. ${ }^{27}$ According to a World Bank report, Bulgaria has made great progress between 2004 and 2010 in reducing the administrative and regulatory burden on the business. In 2008 the World Bank's Doing Business ranked Bulgaria one of the world's top ten reformers, as a reduction in regulations and procedures made it easier to start and conduct a business in Bulgaria. ${ }^{28}$ The same report highlights further achievements, such as reductions in the number of procedures, the time to register, the cost of registration, and minimum capital requirements for opening a business, reduction in corporate taxes and improved regime of paying taxes.

In 2011, the Registry of Administrative Services was launched and a Second Plan for Reducing Administrative Burdens was adopted in 2012. ${ }^{29}$ From the total of 135 measures for 2012 in the plan, 112 were completed. A total of 77 regulatory regimes were relaxed and 10 completely removed. ${ }^{30}$ A project funded by OPAC and the ESF was started, aiming to review and align administrative taxes with clear principles and specific socio-economic priorities. As a result, 12 tariff taxes were removed in 2012. In 2013, another OPAC and ESF-funded project was started on improving investment policy through better regulations and e-government. Specific measures included amendments to the LLARACEA and other laws that eliminated tariffs and taxes. ${ }^{31}$

The Third Action Plan for Reducing Administrative Burdens by $30 \%$ between 2015-2017 was adopted by the Oresharksi government. The plan envisioned 130 measures for reducing the administrative burden that are expected to

25 "Better Regulation for Higher Growth: Bulgaria's Business Regulations - Achievements and Regulations," World Bank, October 2010, Vol I.

262008 Annual Administrative Report. Available at: http://www.strategy.bg/Publications/View. aspx?ld $=81$.

27 Atanassov, op. cit. p. 24.

28 "Better Regulation for Higher Growth: Bulgaria's Business Regulations - Achievements and Regulations," World Bank, October 2010, Vol I.

29 The plan envisioned 247 measures, including removing regulations over entrepreneurial and economic activity, reducing government intervention and reduction of regulatory fees, and reduction of procedures. 2012 Annual Administrative Report. Available at: http://www. strategy.bg/Publications/View.aspx?Id=81.

30 Ibid.

312013 Annual Administrative Report. Available at: http://www.strategy.bg/Publications/View. aspx?ld=81. 
reduce business expenses by BGN 144.5 million annually. ${ }^{32}$ Other initiatives include amendments to the LLARACEA, transposition of EU regulatory regimes, and reduction of regulatory regimes at the municipal level, including reduction of taxes, documents required, and time to process requests. ${ }^{33}$ The second Borisov cabinet adopted a Roadmap for the Development of Public Administration, which put great emphasis on RIA, shared services, complex administrative services, "life cycle" and "business events" principle, and overall improved institutional structure. ${ }^{34}$ Notable projects started by the Borisov II government include "Transformation of the Administrative Service Model" and "Open Government Partnership 2016-2018" with 6 priorities - e-government, citizen participation, open cities, information access, open data and responsible governance. Reducing administrative burden is a top priority for the current Borisov III cabinet. ${ }^{35}$ Some of the latest initiatives include amendments to the Tax and Social Security Procedural Code that would reduce the number of required documents by citizens and business, ${ }^{36}$ and similar amendments to the law on investments and the employment law. ${ }^{37}$

According to a government report, measures taken up to 2015 have reduced the administrative burden on business by $21.7 \%$ of the $30 \%$ reduction envisaged in the third action plan. The reduction has led to cost-saving of BGN 104.5 million a year. ${ }^{38}$ Some of the most important measures were related to the Customs Agency. ${ }^{39}$ A November 2017 report by the deputy prime minister overseeing administrative reform, Tomislav Donchev, states that 170 measures for reducing the administrative burden were adopted out of the total of 605 proposed measures by the current government. 211 measures are in the process of implementation and 224 measures were not started at all. ${ }^{40}$ In 2018, Parliament passed 11 laws to reduce the administrative burden

32 „Административната тежест за бизнеса намалява с 124.4 млн. лева годишно“ [The administrative burden for business reduces by 124.4 million leva annually, 24chasa.bg, September 21, 2017, https://www.24chasa.bg/novini/article/6459323 @ www.24chasa.bg.

332014 Annual Administrative Report. Available at: http://www.strategy.bg/Publications/View. aspx?ld=81.

34 Administrative Reform Report 2016. Available at: https://e-administration-report.eu/.

35 „Спешни мерки за намаляване на административната тежест за гражданите и бизнеса обяви държавата" [The State announced Urgent Measures for Reducing the Administrative Burden], Bnr.bg, June 16, 2017, http://bnr.bg/post/100842770/vlasti-i-institucii-obsajdat-pri-borisov-namalavaneto-na-administrativnata-tejest-i-oblekchavaneto-na-rabotata-s-grajdani.

36 „Предлагат намаляване на административната тежест върху гражданите и бизнеса“ [Proposals for reducing the administrative burden for citizens and business], Actialno.com, September 27, 2017, https://www.actualno.com/politics/predlagat-namaljavane-na-administrativnata-tejest-vyrhu-grajdanite-i-biznesa-news_635387.html.

37 „Приеха редица мерки за намаляване на административната тежест" \{A number of measures adopted for reduction of administrative burden], Manager News, October 18, 2017, https://www.manager.bg/politika/prieha-redica-merki-za-namalyavane-na-administrativnata-tezhest.

38 "Bulgaria claims huge reduction of red tape on businesses," Sofia Globe, April 27, 2016, https://sofiaglobe.com/2016/04/27/bulgaria-claims-huge-reduction-of-red-tape-on-businesses/.

39 "Bulgaria claims huge reduction of red tape on businesses," Independent Balkans News Agency, April 27, 2016, http://www.balkaneu.com/bulgaria-claims-huge-reduction-red-tape-businesses/.

40 „Вече са изпълнени 170 мерки за намаляване на административната тежест“ [170 measures for reducing the administrative burden have been adopted], Trud.bg, Novem- 
in the agricultural sector. ${ }^{41}$ The report on the Third Action Plan for Reducing Administrative Burden indicates an annual reduction of BGN 124.4 million in administrative burden. ${ }^{42}$ Among the most significant recent changes is the established mechanism for information exchange between the National Revenue Agency and the State Agricultural Fund which would save businesses close to BGN 2.6 million annually.

Progress in reducing administrative burden is closely linked and dependent on two important aspects - establishing a legal framework and implementing e-government. The legal framework has been continuously evolving, resulting in reduction in the number and scope of regulatory regimes, transposing EU regulatory regimes, and improving the quality of regulatory regimes, especially through the adoption of RIA. The implementation of e-government has greatly contributed to the reduction of administrative burden. At the same time, the delayed implementation of e-government has posed obstacles to reducing the administrative burden. A 2015 Staff Working Document of the EU commission points to the insufficient development of e-government which limits efforts to increase transparency and reduce the administrative burden. ${ }^{43}$ However, a 2014 report acknowledges a general increase in effectiveness and efficiency, and progress in technological innovation and provision. ${ }^{44} \mathrm{~A}$ major step forward is the e-justice system, the e-services of the Ministry of Interior (including the traffic agency), the property registry and the upcoming integration of the registry with the cadaster.

At the same time, serious problems remain. According to a 2016 Staff Working Document of the European Commission, in spite of the implemented regulatory reforms, the need for reducing the administrative burden and cutting red tape remains significant. ${ }^{45}$ The prime minister argued that a lot of money was spent on various electronic registries, but there is little use of them for the moment. ${ }^{46}$ According the World Bank's Doing Business indicator, Bulgaria ranks $50^{\text {th }}$ and is behind all East European new member states. ${ }^{47}$ An EBRD

ber 24, 2017, https://trud.bg/\%D0\%B2\%D0\%B5\%D1\%87\%D0\%B5-\%D1\%81\%D0\%B0\%D0\%B8\%D0\%B7\%D0\%BF\%D 1\% 8A\%D0\%BB\%D0\%BD\%D0\%B5\%D0\%BD\%D0\%B8-

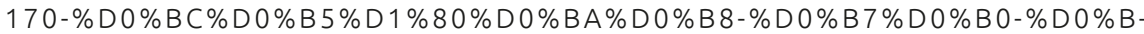
D\%D0\%B0\%D0\%BC\%D0\%B0\%D0\%BB\%D1\%8F\%D0\%B2\%D0\%B0\%D0\%BD/.

41 „Парламентът промени 11 закона с цел намаляване на административната тежест“ [Рагliament passed 11 laws to reduce the administrative burden], Bulgarian Telgraph Agency, Janvary 24, 2017, http://www.bta.bg/bg/c/OF/id/1732019.

42 „Административната тежест за бизнеса е намаляла със 124.4 млн. лева годишно“ [тhе administrative burden has decreased by 124.4 million leva annually], September 21, 2017, https://www.24chasa.bg/novini/article/6459323.

43 SWD P55, 2015. Available at: https://ec.europa.eu/transparency/regdoc/?fuseaction=home

44 "Study on eGovernment and the Reduction of Administrative Burden", European Commission, 2014, p. 71.

45 SWD P54, 2016. Available at: https://ec.europa.eu/transparency/regdoc/?fuseaction=home.

46 „Спешни мерки за намаляване на административната тежест за гражданите и бизнеса обяви държавата" [The State announced Urgent Measures for Reducing the Administrative Burden], Bnr.bg, June 16, 2017, http://bnr.bg/post/100842770/vlasti-i-institucii-obsajdat-pri-borisov-namalavaneto-na-administrativnata-tejest-i-oblekchavaneto-na-rabotata-s-grajdani.

47 Doing Business: Bulgaria, World Bank, http://www.doingbusiness.org/data/exploreeconomies/bulgaria. 
report outlines the top priorities as alleviating procedures for starting a business, getting electricity, and paying taxes. ${ }^{48}$

There are three lessons to be learned: 1) the importance of a sound and continuously improving regulatory framework, 2) the importance of coordination with reforms in other related areas, such as e-government, and among the different levels of government, and 3) the positive effect of EU's external influence and financial support. Another very important aspect is the much broader context of reforms. Reducing the administrative burden is linked to the overall quality of service delivery, the successful implementation of e-government, the effectiveness of the legislative process, the effectiveness of the judiciary, and more. Hence, improvement in this area is linked to overall improvement in governance, strengthening of institutions, and economic growth.

\section{Civil service reform}

Civil service reform in Bulgaria has been largely defined by 1) the domination of the former communist elite, 2) difficulty in overcoming legacies of corruption and politicization, and 3) externally-driven reform efforts with lack of strong political will for reform at the domestic level and lack of clear direction of the reform (Ban et al., 2012). Entrenched former communist elites were reluctant to adopt administrative reform that would reduce their control over the allocation of state resources (Kostadinova and Neshkova, 2013, p. 6), while a weak opposition that failed to win the first post-communist elections was unable to champion reform efforts. As a result, there was no political support for civil service reform domestically and the issue did not reach the agenda before it was pushed externally by the EU. Desire to join the EU and NATO became the main driver behind civil service reform (Ellison, 2007, p. 227). The EU identified public administration reform as one of the key areas that needed to be addressed in order to gain membership. The combination of external pressure and a new government committed to integration in the Euro-Atlantic structures jump-started reform efforts. In addition to external pressure and financial support, the pre-accession process had a very positive effect on the professionalization of the civil service, since the public administration was heavily involved in the pre-accession phase and increasingly responsible for priority setting (Borissova, 1999, p. 3). Interviews with public officials indicate this was the most exciting time in their career as they had the ability to learn best practices from their European counterparts and actively participate in the transposition of EU laws and the establishment of new structures (Ban et al., 2012).

Since the late 1990's all governments have been at least nominally committed to civil service reform and have pursued numerous reform initiatives. The Civil Service Law was continually amended in order to eliminate loopholes and provide a stronger and better legal framework. A lot of focus was placed on

48 "Bulgaria needs to focus on reducing administrative burdens on businesses in 2018 - EBRD," SeeNews, November 23, 2017, https://seenews.com/news/bulgaria-needs-to-focus-on-reducing-administrative-burdens-on-businesses-in-2018-ebrd-592112\#sthash.eLdC8bOh.dpuf. 
professional development, performance evaluation, and competitive compensation. The Operational Programs "Administrative Capacity" and "Good Governance" have been a key source of finance that has also defined strategic goals and specific reform initiatives. Subsequent governments have competed to absorb EU funds and show results that would secure continued EU support. The indefinite extension of the CVM mechanism and the specific recommendations some of which, such as measures to fight corruption, related to civil service, have further contributed to keeping civil service reform on the agenda. Thus, the commitment of all recent governments to civil service reform can be seen as a function of EU financial support through the operational programs tied to results and the pre-accession and post-accession (CVM) conditionality. As one expert has argued, without EU funding, incentives for administrative reform would not exist. ${ }^{49}$ Yet, EU's ability to exercise external pressure has been much greater in the pre-accession period, as evidenced by the fact that most reform efforts were concentrated between 1999-2007, while reform efforts in the last decade have subsided both in terms of commitment and results.

Furthermore, reform initiatives have been much more eagerly embraced by the central administration and have encountered resistance at the local level. Territorial administrations have been consistently slower to implement laws and regulations, and to pursue specific projects and initiatives. For example, territorial administrations have resisted granting civil servant status off public employees, with the rate of implementation being consistently and significantly lower since the adoption of the Civil Service Law. Corruption and politicization have remained a major challenge, particularly at the local level, where the reluctance of new officials to work with staff who have served the previous government has been high. Local administrations have also disposed with much more limited resources, which has further obstructed the ability to modernize the civil service at the local level and render civil service jobs more attractive.

The key goal of the civil service reform has been the transition from a highly politicized, corrupt, and inefficient nomenklatura system to a professional merit-based civil service. Specific objectives include:

- Setting up a legal framework that the provides the foundation of a civil service system;

- Increasing the number and percentage of public sector employees who have civil servant status;

- Establishing open, unbiased, and competitive hiring procedures that counter corruption and politicization tendencies;

- Improve the skills and qualifications of civil servants through professional development activities;

- Introducing fair and competitive compensation system that is tied to performance and can attract new entrants;

49 Interview 2 with Pavel Ivanov, Institute of Public Administration, October 2017. 
- Developing a comprehensive human resource management system that integrates all elements from recruitment, performance evaluation, compensation, professional development, and more.

Compared to other East European countries, civil service reform in Bulgaria can be characterized as belated, externally-driven, and with a poor implementation record (Zankina, 2016). The system has encountered great obstacles in overcoming past legacies and combating high levels of corruption and politicization. The push for reform has been primarily external which puts into question the sustainability of reform efforts. The poor reform record reinforces the traditional low trust in government institutions, further eroding the efficiency of the public sector.

In his typology of civil service reform paths, Meyer-Sahling characterizes civil reform in Bulgaria as "sticking with the old guard", whereby incoming governments show little willingness to work with the administrative staff which served their predecessors in government and where political interference at the top of the civil service continues to contradict attempts to establish professional civil services insulated from politics (Meyer-Sahling, 2004). Dimitrova, in turn, groups East European countries in three categories - full, partial, and no reform - when it comes to reforming the civil service (Dimitrova, 2005). According to her, Bulgaria falls in the group of no reform or what Dimitrova terms "rhetorical reformers" in that it had not adopted any legislation on the issue until the late 1990s. In a more recent study Katsamunska (2010) points to the persistent high turnover of staff, unattractive salaries, which breed opportunities for corruption, and outdated, centralized procedures (p. 56).

Despite two decades of reform efforts, civil service reform faces several key challenges:

- Compensation: the salary gap between the public and private sector remains large. This poses obstacles to attracting and retaining skilled labor, resulting in high turnover and lack of expertise and continuity. There have been several initiatives in this regard, including a new compensation system, which have produced some reduction in turnover and has made jobs, particularly in central administrations, more attractive.

- Evaluation mechanisms have been criticized for failing to provide an objective assessment of performance and create incentives for improved performance. Annual reviews have often taken the form of formality and performance pay has been insignificant in amount to motivate top performers.

- Recruitment still leaves loopholes for politicization and allows for bypassing legal requirements for mandatory exams and competitive hiring procedures. This is evidenced by the fact that most changes in personnel take place through reappointments or the conversion of temporary positions into full positions, none of which requiring an exam and open competition. The latest changes to the law aim to address such loopholes. However, this would still leave other instruments such as restructuring. Frequent re- 
structuring of administrative structures has been used for political ends as an instrument for bypassing the legal protection of civil servants and exercising party patronage and political purging (Zankina, 2016).

- Professional development has had limited impact. According to interviews with experts, a lot of European money was absorbed for professional development, but with little impact. Both interviewed experts agree that this was money not well-spent. According to an expert from the managing authority of the "Good Governance" program, in the previous program period (2007 - 2013) there was no political stability and the OPAC was left on without strategic governance. Consequently, money was spent quite inefficiently in an attempt to satisfy and placate as many units and make employees happy. OPAC funded over 600 projects for trainings, seminars and HR development, while there were no projects for much needed priorities such as digitalization, inter-ministry data exchange or other pressing administrative needs. ${ }^{50}$ Another expert argues that municipalities were given 100,000 BGN for trainings, which proved quite ineffective. In his view, trainings should been done in a centralized way, as opposed to pouring money into private training organizations. ${ }^{51}$

- Corruption remains a deeply-rooted and lasting problem. The January 2017 CVM report highlights the fight against corruption as the area where least progress had been made over the ten years of the CVM..$^{52}$ On the positive side, the most recent amendments to the Law on Public Administration adopted in October 2017 set up a legal framework and common operating standards for the internal inspectorates in the public administration.

Such criticisms notwithstanding, one cannot overestimate the progress that has been made since the time of the communist-era nomenklatura system in all aspects of civil service reform. Bulgaria today has a sound and continuously improving legal framework establishing a professional, merit-based system. Recruitment has been continuously improving to address questions of politicization and close remaining loopholes. Salaries in the public sector have been increasing (by 5.9\% in 2016), ${ }^{53}$ though at a much lower rate than salaries in the private sector. Yet, a new compensation system has created conditions for attracting skilled labor and rewarding good performance. Compared to the 1990s the size of the administration is reduced, while the number and percentage of public employees with a civil servant status has been continuously increasing. Decentralization efforts have improved the capacity of territorial administrations and increased their staffing. Turnover has decreased to

50 Interview with Mariya Hristova, Managing Authority, OPGG, October 2017.

51 Interview with Pavel Ivanov, Institute of Public Administration, October 2017.

52 Report from the Commission to the European Parliament and the Council on Progress in Bulgaria under the Co-operation and Verification Mechanism, January 25, 2017, https://ec.europa.eu/info/sites/info/files/com-2017-43_en.pdf.

532016 Annual Administrative Report: Available at: http://www.strategy.bg/Publications/View. aspx?ld=81. 
under $10 \%$ in 2016 and is even lower in the central administration. ${ }^{54}$ Although lagging in reform efforts, Bulgaria today has a modern civil service.

Civil service reform was a major challenge following the collapse of communism for all East European countries, including Bulgaria. At the outset of democratization, Bulgaria inherited a Soviet-type nomenklatura system of public administration, marked by a fusion of party and state and an intimate relationship between the government and the public administration. The public sector was the only sector, argues Baker (Baker, 1994, p. 55), and political loyalty rather than merit was the only criterion for hiring and promotion. The result was a largely overstaffed and inefficient civil service with no accountability other than to the party, top-down decision-making with no room for management, and absence of any dissent (Ban et al., 2012). Incentives for efficiency were virtually absent, as delay and administrative hurdles created additional opportunities for spoils. The outcome was alienated public servants and endemic corruption - a legacy that has been extremely hard to break to the present day and that has been posing a continuous challenge to building a professional civil service.

Early efforts in public administration reform focused on establishing a legal framework for central and local government and not on civil service. During that time, the structure of the civil service remained largely intact, although it doubled in size. The growth in size was coupled with excessive turnover, particularly among senior civil servants (Borissova, 1999), poor professional skills, lack of training and low pay. These factors made for an inefficient civil service that was further demoralized by allegations of corruption and low standard of living of public employees (Verhereijen and Kotchegura, 1999, p. 92). Poor terms of employment and job insecurity (three-year contracts and no protection of civil servants who were employed under the general labor code) rendered the public sector particularly unattractive, reinforcing the challenges of high turnover and lack of professionalism. Frequent restructuring of ministries and state agencies used as a way to create new spoils positions for the party in power or a way to get rid of politically unsuitable public servants further contributed to high turnover and solidified patronage practices and politicization (Zankina, 2016).

Civil service reform came on the agenda with the start of the negotiations for EU membership, with the EU becoming the key driver of reform. In 1997, the Commission singled out public administration reform as a prerequisite for launching membership negotiations with the second wave of applicants, including Bulgaria (Noutcheva and Bechev, 2008, p. 130). That and a new government clearly oriented towards the Euro-Atlantic structures jumpstarted the reform of the civil service. The Kostov government managed to push through the legislature and adopt the Administrative Law in 1998 and the Law on Civil Service in 1999. Both laws aimed at laying the foundations of a modern public administration system and creating a professional civil service, lim-

542016 Annual Administrative Report: Available at: http://www.strategy.bg/Publications/View. aspx?Id=81. 
iting politicization, which has been a defining characteristic of the post-communist administrative system (Dimitrova, 2002). The government established the Ministry of Public Administration and Reform (1997) and the Institute of Public Administration (2002) which were respectively in charge of overseeing civil service reform and carrying our civil service exams and trainings.

The Civil Service Law set up a system with two types of public employees civil servants protected under the Civil Service Law and non-civil service employees who were under the general labor code and whose contract could be temporary or indefinite. Both categories were included in the newly created in 2000, "Unified classifier of administrative positions." The system has three tracks - manager (reserved for civil servants), experts, and technicians. Civil servants are divided in two categories - junior and senior, with five levels each. Until very recently, recruitment represented a mixed system of unified and departmental approaches. All civil servants are appointed following an open competition. Junior civil servants are appointed following a centralized exam that is organized by the Institute of Public Administration. Those who pass the exam can then be appointed at any junior level position in any of the governmental structures. In addition, individual ministries, agencies, and other governmental organizations carry out their own open competitions for specific positions both at the junior and senior levels. Senior level positions are filled only through this departmental approach. Each level has the appropriate minimum level entry requirements and there is a 6-month trial period for new entrants. The Law on Civil Service was amended several times in response to criticisms including a vague definition of the term civil servant, lack of performance evaluation and performance pay, and contradictions with the labor code. With the adoption of the Civil Service Law, the main efforts were directed towards introducing the civil servant category in central and local administrative units and increasing the number of public employees with civil servant status. By $2001,31 \%$ of public employees in the central administration had a civil servant status, compared to $18 \%$ in the territorial administrations. ${ }^{55}$ Civil service trainings were also a high priority and were funded by USAID, the British Know How Fund, and the EU (PHARE, IPSA and SAPARD programs). ${ }^{56}$

The NDSV government put great emphasis on civil service reform. In 2002, it adopted the Regulation for Performance Evaluation of Civil Servants, and in 2003 the Law for Conflict of Interest. Although the new evaluation system was well-received by civil servants, it was criticized on a number of counts, including inflated evaluations, poorly trained evaluators, and lack of impact on the motivation of civil servants due to the formality of the process and the low performance pay (Tzankova, 2007). In 2004, the government adopted regulations assuring a competitive hiring process of civil servants through a mandatory open and publicly announced competition and a Code of Behavior for Civil Servants that aimed to improve service delivery and increase trust in

552001 Annual Administrative Report: Available at: http://www.strategy.bg/Publications/View. aspx?ld=81.

562000 Annual Administrative Report: Available at: http://www.strategy.bg/Publications/View. aspx?Id=81. 
civil servants. ${ }^{57}$ In 2005 , the government introduced amendments to the Civil Service Law that introduced mandatory annual training in line with the adopted in 2002 "Strategy for Training of Public Administration Employees." 58 Currently there is a 3-months mandatory training for new civil servants and a 3-month mandatory training for anyone promoted to a managerial position. In addition, senior civil servants undergo mandatory annual training carried out by the Institute of Public Administration. In 2005, the government also tied additional pay to performance evaluation, effectively introducing performance pay. Up to that moment, additional pay was based on the base salary and not on performance. The main goal of the NDSV government was to improve the quality and attractiveness of the civil service, as well as to increase recruitment among high-skilled workers and young people. Thus, its focus expanded beyond increasing the number and percentage of public employees with a civil servant status, to also introducing new evaluation procedures, regulating performance pay, and improving the qualifications of public employees. During NDSV's tenure, the size of public administration continued to increase which was linked to the development of the territorial units. ${ }^{59}$

The main priority of the Stanishev government was the launch of the Operational Program "Administrative Capacity" 2007-2013 (OPAC), which proved the main factor for progress in civil service reform in the years to follow. OPAC was placed at the heart of the Strategy for Human Resource Management 2006 - 2013 adopted in 2007. Amendments to the Civil Service Law aimed to address loopholes in the law, which allowed avoiding open competitions for civil service positions through part-time and temporary appointments which are later converted to full-time appointments. ${ }^{60}$ In 2009 , the size of the public administration reached its lowest value since 2003 and at the same time, the number of public employees with a civil servant status for the first time exceeded that of employees not covered by the law, reaching $51 \%{ }^{61}$

The first Borisov government started its tenure by closing the Ministry of Public Administration -- a clear sign of backsliding and a signal that "we are back to the state of chaos", according to former According to former minister, Nikolay Vasilev. ${ }^{62}$ In 2010, GERB introduced amendments to the Civil Service Law which expanded the category of civil servants to additional government units (including the police in the category of civil servants), increasing the number and percentage of public employees with civil servant status. The government continued the tendency of reducing the size of the administration and increasing the salaries. In 2012 the government put a ban on the size of the public administration and pursued an active policy of size reduction, as

572004 Annual Administrative Report: Available at: http://www.strategy.bg/Publications/View. aspx?Id=81.

582005 Annual Administrative Report: Available at: http://www.strategy.bg/Publications/View. aspx?Id=81.

59 lbid.

602005 Annual Administrative Report: Available at: http://www.strategy.bg/Publications/View. aspx?ld=81.

612009 Annual Administrative Report: Available at: http://www.strategy.bg/Publications/View. aspx?Id=81.

62 Interview with Nikolay Vasilev, Sofia, May 9, 2012. 
part of its strategic goal of optimizing the public administration and reducing expenses. Other positive developments included actively implementing the Conflict of Interest Law, resulting in the discharge of several senior civil servants due to corruption and fraud. A major accomplishment was the introduction in 2012 of a new compensation system. The new system restructured the compensation model and introduced several major changes. Bonuses, which were usually tied to revenues in an administrative unit and not to performance, were eliminated. Instead, compensation was tied to performance and closely linked to the annual evaluation. A new matrix was developed with salary ranges for each position, eliminating differentiation based on years of service and stimulating new entrants. The new model made the civil service more competitive in terms of compensation.

The Oresharski government oversaw the completion of the OPAC program and start of the Operational Program "Good Governance" 2014-2020. Among the more notable OPAC projects during that period is the creation of an Integrated Information System for Human Resource Management, which allows self-serving of managers and civil services and handles HR matters from the time of hire to the end of employment. The system started operating at the beginning of 2016. The government adopted a new Strategy for the Development of Public Administration 2014-2020, aligned with the "Good Governance" program. A key priority of the strategy is developing professional and expert governance, as well as civil service objectives at the local level. In line with the strategy, in 2013, the government established Governance Decentralization Council, aimed at improving administrative functions at the local level. The goals of the "Good Governance" program related to the civil service, include developing a flexible administrative structure, improving HR development policies and adopting standards to their successful implementation. The "Good Governance" program will play an important role in the coming years both in terms of identifying and pursuing strategic priorities and financing specific projects and initiatives. The second GERB government (2014-2017) continued the implementation of the "Good Governance" program.

The main accomplishment of the second GERB government were the 2016 amendments to the Civil Service Law which introduced a two-phase recruitment strategy - a centralized exam at step one run by the Institute of Public Administration and second phase intended to assess specialized skills, which is carried out by the specific search commission at each ministry or agency. Only candidates who have passed the first step are allowed to compete in the second, which effectively closes the opportunities for new entrants in the civil service without having passed a competitive and transparent process. This is a significant step in controlling politicization and arbitrary appointments. At the same time, this more centralized procedure does not apply to civil servants transferring from one unit to another, which constitutes the most common pathway to new appointments in the civil service. Transfers are weakly monitored compared to new hires, thus still allowing for politicization and arbitrary practices. However, with time there will be less and less opportunities for occupying positions without passing through the new competitive 
two-steps procedure. Another important initiative is the Plan for Implementing the European Common Assessment Framework of quality control. The Institute of Public Administration is overseeing the process, starting with a pilot project in 48 administrative units. ${ }^{63}$

There are several lessons that can be learned from the Bulgarian example. In the first place is the importance of political will and political dynamics for the outcome of reform efforts. As Meyer-Sahling argues, civil service laws are seldom the expected catalysts for the stabilization, depoliticization and professionalization of the public administration (2004). Instead, political dynamics and party politics have exercised persistent influence over public administration reform, and personnel management in particular. As one expert points out, the efficiency of EU funding does not depend on the form or type of funding, it depends on the willingness of the beneficiary country to do reforms, and no one could convince policy-makers to enact reform. ${ }^{64}$

Second, external pressure and financing is important and can help jump-start reform. Yet, it cannot prevent abuse, as illustrated by the funding spent on trainings. Domestic actors have their own objectives and incentives and can skillfully use external support to further their own agenda. At the very least, if their goals are not aligned with that of the funder, the outcomes of the funded projects can turn out very different from what was originally intended.

Third, long-standing legacies are hard to uproot and have great influence over administrative culture and civil service reform. Despite the conceptual shortcomings of the legacy argument (Meyer-Sahling, 2009), legacy effects have had great influence on the trajectory of civil service reform in Bulgaria. Deeply-rooted and long-standing practices of politicization, corruption, and inefficiency have been resilient to reform efforts. Instead, they have maintain an administrative culture that helps perpetuate inefficiencies, corruption practices, and political patronage. Thus, reform efforts need to be sustained over a prolonged period of time on order to slowly start changing value systems and attitudes.

\section{Conclusion}

Public administration reform in Bulgaria has had one of the worst records among East European countries. The system has encountered great obstacles in overcoming communist legacies and combating high levels of corruption and politicization. The push for reform has been primarily external which puts into question the sustainability of reform efforts. The poor reform record reinforces the traditional low trust in government institutions, further eroding the efficiency of the public sector. Lack of political will and great political instability in recent years have further impeded any previous efforts. The reform has been stop-and-go in nature, with a decreasing commitment (particularly financial) on the part of recent governments. Some success stories do

63 Administrative Reform report 2016. Available at: https://e-administration-report.eu/. 64 Interview with Mariya Hristova, Managing Authority, OPGG, October 2017. 
exist. Some municipalities have been able to benefit from EU funding more than others and to adopt best practices. The key factor for success or failure has been the political will. With widespread and endemic corruption benefitting the power holders, it is unlikely that sustained and meaningful efforts can be made. The external leverage of the $\mathrm{EU}$ is weakening in the context of an overall European crisis of governance. Given that the EU has been the main driver of reform in this area, we can expect to see further backsliding and deprioritization of public administration reform. The overall top-down and centralized approach makes it hard for local governments to be autonomous and be able to drive their own reform efforts. The central government, in turn, fails to address regional differences and disparities, resulting in great territorial inequalities. The best course of action in such context is to empower civil society organizations in the monitoring and reporting and to focus on increased transparency and voice. Support for the senior management level is also critical, as it can offset deficiencies at the political level. Focusing on the civil service, its continued professionalization and professional development can prove a smart strategy to pursue.

The Bulgarian case illustrates that PAR is a complex process influenced by a variety of factors. Reform trajectories may differ despite common legacies and administrative traditions. Specific political choices can reinforce or uproot such legacies and traditions and can either reinforce exiting institutional mechanisms or help institute new ones in their place. External pressure can go a long way in incentivizing government officials and civil servants to stay on the reform track, however, such leverage has its limitations and can often lead to legal transposition without actual implementation to follow. The country-specific context and the interplay of the various factors determine a unique reform trajectory and outcome, which puts into question the transferability of public management models and traditions. The Bulgarian case further confirms the importance of political will (Kostadinova and Neshkova, 2013) and the limitation of the top-down approach (Nakrošis, 2017). More importantly, this article illustrates the importance of a wholistic approach to the study of administrative reform and dynamics that combines theoretical with country-specific knowledge, as well as the value of qualitative studies that complement quantitative comparative studies. 


\section{References}

Baker, R. (1994). Democracy versus Bureaucracy: Transforming the Nature of the Civil Service in Bulgaria. In: R. Baker, ed., Comparative Public Management: Putting US Public Policy and Implementation in Context. Westport, CT: Praeger Publishers, pp. 53-65.

Baker, R. (ed.) (2002). Transitions from Authoritarianism: The role of the Bureaucracy. Westport, CT: Praeger.

Ban, C. and Huddleston, M. (1999). Exporting Administrative Reform to Eastern Europe and the Former Soviet Union: the Role of Consultants in Technical Assistance. Paper presented at the Annual Meeting of the Association of Public Policy and Management.

Ban, C. et al. (2012). After Conditionality: Progress or Backsliding in Civil Service Reform in the New Member States of the European Union? Paper presented at the $20^{\text {th }}$ annual conference of NISPAcee (Network of Institutes and Schools of Public Administration in Central and Eastern Europe), Ohrid, North Macedonia, 23-26 May 2012.

Borissova, O. (1999). Public Administration Reform in Bulgaria. In E. von Breska and M. Brusis, eds., Central and Eastern Europe on the Way Into the EU: Reforms of the Regional Administration in Bulgaria, the Czech Republic, Estonia, Hungary, Poland and Slovakia. Working papers, Center for Applied Policy Research, Munich, pp. 1-13.

Brusis, M. (2004). Europeanization, Party Government of Legacies? Explaining Executive Governance in Bulgaria, the Czech Republic, and Hungary. Comparative European Politics, 2, pp. 163-194.

Camyar, I. (2010). Europeanization, Domestic Legacies and Administrative Reforms in Central and Eastern Europe: A Comparative Analysis of Hungary and the Czech Republic. Journal of European Integration, 32 (2), pp. 137-155.

Demmke C. and Moilanen, T. (2010). Civil Services in the EU of 27: Reform Outcomes and the Future of the Civil Service. Frankfurt: Peter Lang.

Dimitrova, A. (2002). Enlargement, Institution-Building and the EU's Administrative Capacity Requirement. West European Politics, 25(4), pp. 171-190.

Dimitrova, A. (2010). The New Member States of the EU in the Aftermath of Enlargement: do New European Rules Remain Empty Shells? Journal of European Public Policy, 17(1), pp. 137-148.

Ellison, B. (2007). Public Administration Reform in Eastern Europe: A Research Note and a Look at Bulgaria. Administration and Society, 39 (2), pp. 221-232.

Epstein, R. A. and Sedelmeier, U. (2008). Beyond Conditionality: International Institutions in Postcommunist Europe after Enlargement. Journal of European Public Policy, 15(6), pp. 795-805.

Epstein, R.A. and Jacoby, W. (2014). Eastern Enlargement Ten Years On: Transcending the East-West Divide? Journal of Common Market Studies, 52(1), pp. 1-16.

European Commission. (2019). Report from the Commission to the European Parliament and Council on Progress in Bulgaria under the Cooperation and Verification Mechanism. At <https://ec.europa.eu/info/sites/info/files/ progress-report-bulgaria-2019-com-2019-498_en.pdf>, accessed 1 June 2019. 
European Commission. (2018). Report from the Commission to the European Parliament and Council on Progress in Bulgaria under the Cooperation and Verification Mechanism. At <https:/ec.europa.eu/info/sites/info/files/ progress-report-bulgaria-com-2018-850_en.pdf>, accessed 2 May 2019.

European Commission. (2016). Report from the Commission to the European Parliament and the Council on Progress in Bulgaria under the Cooperation and Verification mechanism. At <http://ec.europa.eu/cvm/docs/ com_2016_40_en.pdf>, accessed 15 May 2019.

Eurostat Academic Study. (2010). At <https://ec.europa.eu/eurostat/statisticsexplained/index.php?title=File:Academic_study_2010.png>, accessed 10 June 2019.

Frye, T. (2010). Building States and Markets after Communism: the Perils of Polarized Democracy. Cambridge: Cambridge University Press.

Gurov B. and Zankina, E. (2013). Populism and the Construction of Political Charisma: Post-transition Politics in Bulgaria. Problems of Post Communism, 60(1), pp. 3-17.

Järvalt, J. and Randma-Liiv, T. (2010). Public Sector HRM: the Case of No Central Human Resource Strategy. Baltic Journal of Management, 5(2), pp. 242-256.

Katsamunska, P. (2010). Good Governance and Reform of Public Administration in Bulgaria. Economic Alternatives, 1, pp. 51-60.

Kitschelt, H. et al. (1999). Post-communist Party Systems: Competition, Representation, and Inter-party Cooperation. Cambridge: Cambridge University Press.

Kostadinova, T. and Neshkova, M. (2013). Explaining the Incidence of Administrative Reform in Eastern Europe. In M. Vintar et al., eds., The Past, Present and the Future of Public Administration in Central and Eastern Europe. Bratislava: NISPAcee Press, pp. 91-107.

Kullman S. and Wollmann, H. (2014). Introduction to Comparative Public Administration: Administrative Systems and Reforms in Europe. Edward Elgar Publishing.

Meunier, S. and McNamara, K. (eds.) (2007). Making History: European Integration and Institutional Change at Fifty. Oxford: Oxford University Press.

Meyer-Sahling, J. (2004). Civil Service Reform in Post-Communist Europe: The Bumpy Road to Depoliticisation. West European Politics, 27(1), pp. 71-103.

Meyer-Sahling, J. (2011). The Durability of EU Civil Service Policy in Central and Eastern Europe after Accession. Governance, 24(2), pp. 231-260.

Meyer-Sahling, J. (2009). Varieties of Legacies: A Critical Review of Legacy Explanations of Public Administration Reform in East Central Europe. International Review of Administrative Sciences, 75(3), pp. 509-528.

Meyer-Sahling, J. and Veen, T. (2012). Governing the post-communist state: government alternation and senior civil service politicization in Central and Eastern Europe. East European Politics. Doi:10.1080/13523279.2011.635651

Meyer-Sahling, J. and Yesilkagit, K. (2011). Differential Legacy Effects: Three Propositions on the Impact of Administrative Traditions on Public Administration Reform in Europe East and West. Journal of European Public Policy, 18(2), pp. 311-322.

Nakrošis, V. (2017). The Quantitative and Qualitative Analysis of Public Administration reforms in Post-Communist Countries. Baltic Journal of Political Science, 6, pp. 7-28. 
Noutcheva, G. and Bechev, D. (2008). The Successful Laggards: Bulgaria and Romania's Accession to the EU. East European Politics and Societies, 22(1), pp. 114-144.

Operational Program "Administrative Capacity" (2015). Annual Report on the Progress of Operational Program 'Administrative Capacity' 2014". At <http:// www.opac.government.bg/userfiles/pages/files/annual_reports/1/\%D0\%93 \%D0\%BE\%D0\%B4\%D0\%B8\%D1\%88\%D0\%B5\%D0\%BD_\%D0\%B4\%D0\%BE \%D0\%BA\%D0\%BB\%D0\%B0\%D0\%B4_2014.pdf>, accessed 12 May 2019.

Peters, B. G. (1999). Institutional Theory in Political Science: the 'New Institutionalism. London: Pinter.

Pitlik, H. et al. (2012). Excellence in Public Administration for Competitiveness in EU Member States. Vienna: Austrian Institute of Economic Research (WIFO).

Randma-Liiv, T. (2005). Demand- and Supply-based Policy Transfer in Estonian Public Administration. Journal of Baltic Studies, 34(4), pp. 467-487.

Schimmelfennig, F. and Sedelmeier, U. (eds.) (2005). The Europeanization of Central and Eastern Europe. Ithaca: Cornell University Press.

Sedelmeier, U. (2008). After Conditionality: Post-Accession Compliance with EU Law in East Central Europe. Journal of European Public Policy, 15(6), pp. 806-825.

Shoylekova, M. (2007). Executive Configuration and Legislative Management: Experiences from Bulgaria. In M. Brusis et al., eds., Strategic Policymaking in Central and Eastern Europe. Bratislava: NISPAcee Press, pp. 19-39.

State Administration Reports 2000-2018. At <http://www.strategy.bg/ Publications/View.aspx?lang=bg-BG\&categoryld=\&ld=81\&y=\&m=\&d=>, accessed 12 May 2019.

Szarek-Mason, P. (2010). The European Union's Fight Against Corruption. Cambridge: Cambridge University Press.

Thijs, N. and Mackie, I. (2016). Debriefing Paper. EIPA Workshop in Bulgaria.

Thijs, N. et al. (2018). A Comparative Overview of Public Administration Characteristics and Performance in EU28. European Commission.

Trauner F. (2009). Post-accession Compliance with EU Law in Bulgaria and Romania: A Comparative Perspective. In F. Schimmelfennig and F. Trauner, eds., Post-accession Compliance in the EU's New Member States. European Integration Online Papers, Special Issue, 2(13).

Tzankova, M. (2007). Civil Servant's Attitudes towards the Existing Performance Evaluation System. Economic Alternatives, 3, pp. 138-150.

Vachudova, M. (2007). Historical Institutionalism and the EU's Eastward Enlargement. In S. Meunier and K. McNamara, eds., Making History: European Integration and Institutional Change at Fifty. Oxford: Oxford University Press.

Verheijen, T. and Kotchegura, A. (1999). Civil Service Systems in Central and Eastern Europe, Civil Service Systems in Comparative Perspective. Northampton, MA: Edward Elgar Publishing.

World Bank (2006). EU-8: Administrative Capacity in the New Member States: The Limits of Innovation? Report number: 36930-GLB.

Zankina, E. (2016). Backdoor Politics: Politicization through Restructuring in the Bulgarian Civil Service. East European Politics, 33(2), pp. 291-308.

Zankina, E. (2018). Public administration characteristics and performance in EU28: Bulgaria. In N. Thijs et al., eds., A Comparative Overview of Public 


\section{Emilia Zankina}

Administration Characteristics and Performance in EU28. European Commission, pp. 66-94.

Zankina, E. (2010). Transformation of the Bulgarian Political Elite in the Period of Transition. Its Impact on the Transition Process, ProQuest LLC. 